\title{
HUMAN FACTOR IN THE TASKS OF ENSURING FUNCTIONING SAFETY OF COMPLEX TECHNICAL OBJECTS
}

\section{WPLYW CZYNNIKA LUDZKIEGO NA BEZPIECZEŃSTWO FUNKCJONOWANIA ZŁOŻONYCH OBIEKTÓW TECHNICZNYCH}

\author{
Olga Korostil $^{1)}$, Jurij Korostil ${ }^{2)}$ \\ ${ }^{1)}$ Ukraińska Akademia Drukarstwa, Ukraina, \\ ${ }^{2)}$ Akademia Morska w Szczecinie, Polska,
}

\begin{abstract}
The paper describes research of problems related to detecting a negative influence of human factors on technologic process in complex technical objects that can occur from the side of maintenance staff. Analysis is performed of psychological aspects of occurrence of human factors, as well as of interconnections between psychological and technical aspects, related to occurrence of human factors, that can lead to malfunctions in technical objects.
\end{abstract}

Keywords: emotional image, maintenance staff, human factor, ecral analysis, diagnostics.

Streszczenie: $W$ pracy opisano badania problemów, zwiazanych $z$ negatywnym wplywem czynnika ludzkiego na procesy technologiczne w złożonych technicznych obiektach, wynikajace $z$ działalności personelu obstugującego. $W$ pracy przyprowadzono analize czynników ludzkich oraz ich aspektów psychologicznych. Przeprowadzono analize związów między psychologicznymi $i$ technicznymi aspektami, które moga doprowadzić do powstania niesprawności w obiektach technicznyc.

Stowa kluczowe: emocjonalny obraz, personel obstugujący, czynnik ludzki, analiza ekratna, diagnostyka. 
Human factor in the tasks of ensuring functioning safety of complex technical objects Wpływ czynnika ludzkiego na bezpieczeństwo funkcjonowania złożonych obiektów...

\section{Introduction}

For a wide range of complex technical objects $(C T O)$, regardless of an automation level of their control, having maintenance staff $(S P)$ is necessary. Maintenance staff consists not only of persons located directly at CTO, but also persons located outside of CTO that influence or take part in controlling a technologic process (TP) of the corresponding CTO. An example of this $S P$ can be persons performing remote control of certain $C T O$ [1].

The human factor $(H F)$ in tasks of safety of $C T O$ is commonly understood as such human actions to the CTO control system that lead to negative consequences in CTO functioning processes. To implement the possibility of a constructive research of $H F$ influence on a technologic process of $C T O$ object, the following conditions are introduced.

Condition 1. During $H F$ influence on $T P$ the parameters of $T P$ can exceed the acceptable boundaries as a result of unacceptable way of controlling $T P$ by certain members of $S P$.

Unacceptable control is control not foreseen by the corresponding manuals and authorization of a certain member of $S P$.

Condition 2. Human factor $H F$ as a negative influence of a member of $S P$ on a process TP of CTO object can occur as a result of occurrence or change in emotional state of a member of $S P$ that lead to one or another controlling actions performed by the corresponding member of $S P$.

Various emotional states of people are quite widely researched by psychologists because it is necessary to solve a whole series of practical tasks [2]. This research, among other tasks, is oriented towards solving the next tasks:

- determining the reason of change in emotional state,

- establishing dependencies between various emotional states,

- determining the forms of physical manifestation of various emotional states.

There can be quite a few reasons for emotional state of a person to change, for example, change in a situation that $C T O$ or the participant of $S P$ himself falls into, and so on. Within the current paper, let us assume that occurrence of a certain emotional state or its change in a member of $S P$ is only caused as a result of giving him certain information. In order to differentiate such information from its other types, we will call it sensitive information (ISe). Sensitivity of information is closely related to emotional states of single members of $S P$, which causes its personalization. Sensitive information can be wrong information regarding the current state of $T P$, it can represent true information regarding occurrence of a critical state in $T P$, however, regardless of its essence, information can be formed in such a way that, when being perceived by a certain member of $S P$, it can lead to occurrence or change of emotional state of a person, which will lead to activating the human factor that will have a negative influence on $T P$. 


\section{Psychological features characterizing the human factor}

Research in the area of psychology has proved the existence of central emotions that are basic, examples of which are aggression, fear, anxiety, generosity, anger and others. On the basis of these emotions, a whole series of secondary and intermediate emotions can appear. These emotions cause stress states, when people from $S P$ can activate their negative influence on $T P$. A feature of human behavior in a stress state lies in the fact that it is difficult to connect the stress state $S p_{i} \in S P$ and specific actions of certain $S p_{i}$ to $T P$. To solve this task, a set of design strategies is used, examples of which are associative, expressive, constructive strategy and others. Ecral strategy and, respectively, ecral analysis are intensively developing, that unite, to a degree, the possibilities of other analysis methods and extend their possibilities due to using reductive-associative logics and are emotionally controlled reduction of associations. Within this strategy, along with solving other tasks, dependencies are determined between various emotional states, for example, an emotion that corresponds to the sad state, converts to irritability, which transforms to strong suspicion and, in the end, goes to fear. In this case, fear is central emotion that directly affects human behavior.

In technical application of results of psychological research, the main attention is focused on practical possibilities of their usage. The first of these practical aspects is the possibility to relate human psychological states to physiologic parameters, values of which are related to the corresponding emotional state of a person. This possibility exists thanks to the fact that various emotional states manifest themselves in changes of values of parameters that characterize muscle tension in different parts of the human body, cause various slightly noticeable movements of various body parts and so on. These aspects of manifesting the emotional state of a person are based on empathic reactions of a process of motor-kinematic identification. Besides, identification of human emotions is based on analysis of handwriting, that is very sensitive to the emotional state of a person, on analysis of voice change during a conversation and on the whole series of other physiologic parameters. In order to be able to solve diagnostic tasks and, in the end, tasks of protecting $T P$ from $H F$, it is necessary to create a psychological image for each $S p_{i} \in S P$. Ecral strategy calls for detecting, at the first stage, the central emotions specific for a certain person. At the second stage, ecral-motivational analysis is implemented, thanks to which an incentive of human behavior is determined.

Practically, the task of creating psychological and emotional image $\left(P E o_{i}\right)$ for $S p_{i}$ can be solved on the basis of using a system $(S T P)$, that is a fusion of simulator systems and a system that implements polygraph technologies [3,4]. To form groups $S P\left(C T O_{i}\right)$ or single $C T O_{i}$ some of methods used in $S T P$ are used. 
Human factor in the tasks of ensuring functioning safety of complex technical objects Wpływ czynnika ludzkiego na bezpieczeństwo funkcjonowania złożonych obiektów...

Using $P E o_{i}$ in tasks of ensuring safety of $C T O_{i}$ functioning is not limited by just choosing a certain membership of $S P$, members of which correspond to certain types of $P E o_{i}$.

During the maintenance of $C T O_{i}$ unforeseen external factors $\left(Z f_{i}\right)$ can occur, that could lead to influence not only on the $C T O_{i}$ object itself, but also on the current state of $P E o_{i}$, that can cause changes in emotional state of $S p_{i}$ and, as a result, occurrence of $H F$. Because of this, the following tasks have to be solved:

- modeling the change processes in $P E o_{i}$ that can occur under the influence of $I S e$, occurring as a result of an influence on $C T O_{i}$ of factors $Z f_{i}$,

- predicting the possibility of $H F_{i}$ occurrence, activated by the corresponding $S p_{i}$,

- developing a method of determining sensibility of information that is intended to be given to $S p_{i}$,

- determining the methods of withstanding the possible $H F_{i}$, that occur during interaction of $S p_{i}$ with the control system of $T P\left(C T O_{i}\right)$,

- identifying the influence of $H F_{i}$ on $T P$ based on analysis of diagnostic parameters, that is performed by a diagnostic model $(D M)$.

\section{Task of detecting the influence of a human factor on $\operatorname{TP}\left(C T O_{i}\right)$}

In order to be able to solve the task of detecting a negative influence of $H F_{i}$ on $T P\left(C T O_{i}\right)$, we have to formalize description of basic components that cause the occurrence of $H F_{i}$. One of these basic components is an emotional model of a single $S p_{i}$ [5]. Based on data of psychological research of certain individuals, we can assume that the corresponding data that describe objects are $P E o_{i}$ and quite difficult to describe using mathematical formal tools with sufficient relevance and constructiveness. To describe these objects, using text models $\left(T M_{i}\right)$ is reasonable [6]. According to concepts of $T M_{i}$, they are text forms of description of the corresponding object in a normalized form in user's native language. To use $T M_{i}$, semantic vocabularies $S c_{i}$ have to be used, that describe the subject area of objects that use $T M_{i}$. Analysis and synthesis of $T M_{i}$ is implemented on the basis of using semantic parameters $\sigma_{i}^{r}\left(x_{i}, x_{j}\right)$, interpretation of which is formed on the basis on using descriptions of a subject area of $T M_{i}$. Because $P E o_{i}$ is formed on the basis of ecral analysis that provides for using reductive-associative logics, this circumstance has to be represented in the corresponding $T M_{i}$ that describe $P E o_{i}$. Let us introduce the follo definition.

Definition 1. A text model $T M_{i}$ is called reductive-associative if it consists of single text fragments $t m_{i j}$ that describe associations $A s_{i j}$ which are used in ecral analysis, while $A s_{i j}$ are united with reductive links, which is described by this relation:

$$
T M_{i}\left(P E o_{i}\right)=F\left(A s_{i j}, R_{i}\right),
$$


where $A s_{i j}$ are single associations described as $t m_{i j}, R_{i}$ is a reduction system that describes links between single $t m_{i j}, F$ is a function that describes the way to use reductions $r_{i j} \in R_{i}$, or the structure of the corresponding $T M_{i}$.

Let us review in more detail the concept regarding what texts are included in $T M_{i}$ in case when the latter describes emotions.

According to definitions listed in psychology, an emotion is a psycho-physiologic feature of a brain, typical for a person, that allows to evaluate situations and the corresponding body states that occur as sensible experience as a consequence of influence of factors of internal and external environment [7]. Let us review concepts of emotions from the point of view of their projection on technical using of the corresponding concept.

Definition 2. An emotion is a characteristic that determines the choice of one or another decision in a situation that occurs relating to a person without using processes of analysis, basis and consequences of making one or another decision.

Definition 3. Depth of emotion is determined by number of possible or available decisions, among which, relying on an emotion and obtained information of ISe type, one of them is chosen without preliminary analysis of the consequences of the corresponding action.

Formally, this definition is described by a relation:

$$
\mu\left(E m_{i}\right)=\sum_{i=1}^{n} d_{i},
$$

where $d_{i}$ is a single decision that is made by $S p_{i}$.

Besides depth of emotion $\mu\left(E m_{i}\right)$, a concept is used of a degree of an emotion belonging to a certain type of the central emotion, or we will discuss the degree of an emotion type, written as $\pi\left(E m_{i}\right)$. In psychology, an emotion type is determined on the basis of the type of feeling that characterizes a physical or physiological state of a person. In case of a technical interpretation of this concept, the situation is more complicated. It is related to the nature of decisions that can be made when certain emotion is present, which is determined by an emotional image $P E o_{i}$ and by obtaining information of ISe type. The decision nature, or type, is determined on the basis of evaluating the consequences of implementation one or another decision that is related to the corresponding $T P$. Let us assume that among all decisions $d_{i j} \in D_{i}$ there is a decision $d_{i j}^{*}$, implementing which ensures the greatest degree of influence on $T P_{i}$ from the point of view of affecting this process. In this case, let us assume that $d_{i j}^{*}$ defines the type of emotion which, unlike terminology common in psychology, will be called a term that interprets the state of TP the process goes to after making a decision $d_{i j}^{*}$ by a person. For example, if after the corresponding influence of $H F_{i}$ on $T P$ the corresponding process goes into 
Human factor in the tasks of ensuring functioning safety of complex technical objects Wpływ czynnika ludzkiego na bezpieczeństwo funkcjonowania złożonych obiektów...

a critical state, the emotion will be called critical. If among available at the $t_{i}$ moment decisions $D_{i}$ there is no decision of $d_{i j}^{*}$ type, emotion that chooses one of the set $D_{i}$ of decisions will be called less critical. This characteristic of emotion will be called the degree of approximation of the corresponding emotion $E m_{i}$ to its maximal efficiency and will be written as $\pi\left(E m_{i}\right)$. Obviously, in case when $E m_{i}$ is one of critical emotions, we can assume that $\pi\left(E m_{i}\right) \in A s_{i j}\left(E m_{i}\right)$. This means that on the basis of emotion $\pi\left(E m_{i}\right)$, when giving certain information of $I S e_{i}$ type, a decision $d_{i j}$ can be chosen that is less critical towards $T P$.

Definition 4. A degree of belonging of emotion $\pi\left(E m_{i j}\right)$ to $E m_{i}$ type is determined by a degree of efficiency of $E m_{i j}$ influence on $T P$.

Definition 5. A decision $d_{i j}$ chosen on the basis of emotion $E m_{i}$ and obtained information of $I S e_{i}$ type is maximal if it corresponds to the decision that leads to ensuring the maximum effect of influencing the functioning process of the corresponding $T P$.

The above-mentioned statements lead to the conclusion that an emotion type as interpreted in a technical subject area, unlike an emotion type in psychology, is determined on the basis of analysis of nature of influence on $T P$ that is performed by $H F_{i}$ affecting $T P$, initiated by the corresponding sensitive information $I S e_{i}$. For instance, if an emotion $E m_{i j}$ that is psychologically interpreted as "fear" activates, together with the corresponding $I S e_{i}$, an influence on $T P$ represented as $H F_{i}$, and this influence leads to malfunction occurring in $\mathrm{CTO}_{i}$, then relating to the technical subject area this emotion is defined by a term "damage". Concepts of malfunctions in technical objects are widely researched in the area of technical diagnostics, which allows to use the correct interpretation of malfunctions $[8,9]$. Thus, in order to transfer interpretation of $E m_{i j}$ emotion from a psychological interpretation area to interpretation in a technical subject area, it has to be fused with the corresponding $I S e_{i}$, and then we will obtain interpretation of this emotion in a technical area. Formally, this transformation can be written by a relation:

$$
\left\{\left[\operatorname{Ps}\left(E m_{i j}\right)\right] \&\left[I S e_{i}\left(E m_{i j}\right)\right]\right\} \rightarrow T h\left(E m_{i j}\right) .
$$

A psychological image $P E o_{i}$ of a person $S p_{i}$ can change during the functioning process because of various factors. So, during the $T P\left(C T O_{i}\right)$ functioning process, within the possibilities of technical support $S P\left(C T O_{i}\right)$, single $S p_{i}$ are periodically tested [10]. These tasks are solved by the part of $S P\left(C T O_{i}\right)$ that is located outside of $C T O_{i}$, which allows to exclude from $\operatorname{TP}\left(C T O_{i}\right)$ maintenance subjective factors that can occur in the group $\operatorname{SP}\left(C T O_{i}\right)$ located inside $C T O_{i}$. 


\section{Summary}

In this paper, one of approaches has been developed to interpret the reasons of decrease of safety level of $C T O_{i}$ functioning process, that is a human factor. Interconnections are researched between psychological factors that characterize a person and technical factors that can be negatively influenced on by human factors. Thanks to research of interconnections between emotions that define the state of a person and human factors that can cause a negative influence on a control system of $T P\left(C T O_{i}\right)$, it is possible to detect such an influence. Detailed analysis of technical aspects related to the human factor and psychological features of maintenance staff allows to determine the nature of occurrence of the human factor, which allows to take it into account when designing safety systems of complex technical objects.

The given analysis of interconnection between psychological reasons of occurrence of the human factor and its technical interpretation allows to solve the whole series of tasks related to detecting such factors and withstanding their negative influence on a complex technical object.

\section{References}

[1] Bowers P. Unconventional Aircraft. Moscow: Mir, 1991 - 320 p.

[2] Kristensen G., Meister D., Foley P. and others. Human Factor. In 6 volumes. V. 1. Ergonomics as a complex scientific and technical discipline. Moscow: Mir,1991. -673 p.

[3] Nedzelskiy I.I. Nautical navigational simulators: problems of choice. SaintPetersburg: SNC RF-CSRI "Elektropribor", 2002. - 220 p.

[4] Zhurin S.I., Ilyushin M.V. Review of modern polygraphs. // Mir i bezopasnost. - 2003. N2, - p. 13-17.

[5] Vilunas V.K. Psychology of emotional phenomena. Moscow: MSU, 1976. $211 \mathrm{p}$.

[6] Yuriy Korostil, Olga Korostil . Analysis and interpretation oftext models // Journal of KONBiN. Safety and reliability system: Wydawnictwo Instytutu Technicznego Wojsk Lotniczych. Warszawa, 2012. - N 4 (24). - pp. 51-56. ISSN 1895-8281.

[7] Emotional influence in strategic marketing. Kyiv: Published by Vedi Art Print, 2005. $-352 \mathrm{p}$.

[8] Technical tools of diagnostics: a reference book/V. V. Klyuev, P. P. Parchomenko, V. E. Abramchuk and others; edited by V. V. Klyuev. Moscow: Mashinostroyenie, 1989. - 672 p. 
Human factor in the tasks of ensuring functioning safety of complex technical objects Wpływ czynnika ludzkiego na bezpieczeństwo funkcjonowania złożonych obiektów...

[9] Kostyukov A.V., Kostyukov V.N. Increasing of operational effectiveness of enterprises on the basis of real-time monitoring. - Moscow: Mashinostroyenie, 2009. - $192 \mathrm{p}$.

[10] Zhurin S.I., Panin O.A. Comparing methods of personnel check-up. // Mir i bezopasnost. - 2003. N3, - p. 30-32.

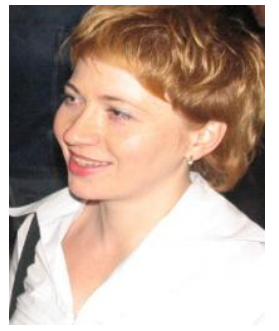

Olga Korostil Doctor of Science, Ukrainian Academy Printed, Lvov

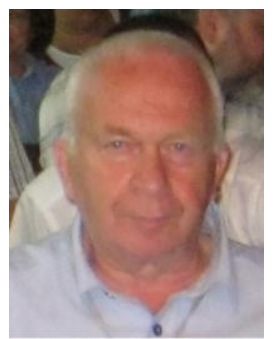

Juri Korostil Professor Doctor of Science, Maritime University of Szczecin, Poland 